\title{
ECONOMIC ANALYSIS OF URBAN ROAD NETWORK WITH VARIOUS SCHEDULED AND RESPONSIVE MAINTENANCE ALTERNATIVES
}

\author{
Tanuj Chopra ${ }^{1}$, Manoranjan Parida ${ }^{2}$, Naveen Kwatra ${ }^{3}$, Sahil Kamotra ${ }^{4}$
}

\begin{abstract}
The study carried out is to establish HDM-4 model for engineers to foresight economic, social and decisive investment decisions. Road deterioration model predicts complex interaction of vehicles with pavement surfaces and its prediction is done on the basis of International Roughness Index (IRI). For urban roads different maintenance rehabilitation strategies are done on time bound maintenance and responsive maintenance for optimization. The result of the study is to suggest changes keeping in mind about the structural and functional evaluation with regard to economy for urban roads. HDM-4 deterioration models are tweaked for Indian National Highway Road Network to keep in check Net Present Value (NPV)/Capital Investment are prime concerns for prioritization.
\end{abstract}

Keywords: Economy Prioritization, Fund Allocation, HDM-4, Road Deterioration, Urban Road Pavement.

\section{INTRODUCTION}

Road transport invigorates economy of nation. The road network provides accessibility of goods from one place to another by means of motorized or non-motorized carriages. The cost of the road is very less as compared to other means of transportation. The roads are to be prevented from deterioration by providing remedies in time otherwise will lead to increase in user cost, accident and travel time. There might be a greater challenge in order to sustain its standards for smooth functioning in upcoming years. Indian Road network is the second largest road network in the world. Thus, government is paying heed to nurture the roads by providing funds and its effective usage in their upbringing for positive outcomes. The focus of present study is on Indian urban and rural networks and need for their maintenance.

\subsection{Delinquencies of Present Road Infrastructure}

\subsubsection{Calibre of Roads Qualitatively}

The quality of existing roads is not good enough in spite of such big network of roads. This is due to the gap between the allocations and requirements which are increasing with course of time. The damage constraints are increasing due to age of roads which are leading to distress like cracking, ravelling and potholing on the surface. These distresses combine action with traffic and environmental factors give boost to the vulnerabilities. These factors deteriorate the road conditions which give rise to problem of accommodating pavement strength within limited budget.

\subsubsection{Amplification of traffic and its effects}

\footnotetext{
${ }^{1}$ Department of Civil Engineering, Thapar University, Patiala, India

${ }^{2}$ Department of Civil Engineering, Indian Institute of Technology, Roorkee, India

${ }^{3}$ Department of Civil Engineering, Thapar University, Patiala, India

${ }^{4}$ Department of Civil Engineering, Thapar University, Patiala, India
} 
Traffic is rapidly increasing on Indian Roads which put great strain upon existing roads. At present growth rate is pre assumed to be $7.5 \%$ ( IRC-37, 2015)[5]. There is increase in axle loads which might not be compatible for present traffic growth due to least change. Thus, the effects are deteriorating pavement quality due to movement of freight vehicles whose weights are violating legal limits. Also, the damage caused to sub-grade which increase the weakening of the overlaying layers.

\section{METHODOLOGY}

\subsection{Sections selected of Urban Road}

Patiala city consists of 52 sections of urban road network and they come under Punjab Roads and Bridges Development Board. The selected sections of road consist of "Asphalt Mix on Asphalt Pavement" type and the pavement width varies from $6 \mathrm{~m}$ to $9.2 \mathrm{~m}$ and the major road sections are two lane. The selected road section details are shown below in Table 1 and Table1.1.

Table 1: Geometric Details of Road Sections

\begin{tabular}{|c|c|c|c|}
\hline $\begin{array}{c}\text { Pavement } \\
\text { Type }\end{array}$ & $\begin{array}{c}\text { Width } \\
(\mathbf{m})\end{array}$ & $\begin{array}{c}\text { Shoulder } \\
\text { Width }(\mathbf{m})\end{array}$ & Number of Lanes \\
\hline AMAP & 9.20 & 1.70 & 2 \\
\hline AMAP & 7 & 1.25 & 2 \\
\hline AMAP & 6 & 1.60 & 2 \\
\hline
\end{tabular}

Table 1.1 Classification of selected road sections

\begin{tabular}{|l|l|l|l|l|l|}
\hline Section I.D. & Name & $\begin{array}{l}\text { Speed Flow } \\
\text { Type }\end{array}$ & $\begin{array}{l}\text { Traffic Flow } \\
\text { Pattern }\end{array}$ & Category of road & Climate Zone \\
\hline RUP-01 & Rajendra Road & $\begin{array}{l}\text { Two-Lane } \\
\text { Wide }\end{array}$ & Inter-urban & Secondary or Main & Subtropical/Hot \\
\hline RUP-02 & Sectarian Road & $\begin{array}{l}\text { Two-Lane } \\
\text { Standard }\end{array}$ & Inter-urban & Secondary or Main & Subtropical/Hot \\
\hline RUP-03 & Tripuri Road & $\begin{array}{l}\text { Two-Lane } \\
\text { Narrow }\end{array}$ & Inter-urban & Tertiary or Local & Subtropical/Hot \\
\hline
\end{tabular}

The sections RUP-01 as well as RUP-02 are two lane divided carriageway whereas section RUP-03 is a single undivided carriageway. Both RUP-01 and RUP-02 are either main or secondary roads whereas RUP-03 comes under the category of local or tertiary roads.

\subsection{Pavement Data}

Pavement data as per the records of PWD(Public Works Department) and Municipal Corporation Patiala, India which are recorded from year 2011 to 2015 stating the thickness, construction, rehabilitation, surfacing and preventive treatments. Details of pavement data are stated in Table 2 below:

Table 2: Pavement history data

\begin{tabular}{|c|c|c|c|c|c|c|c|}
\hline Section ID & $\begin{array}{c}\text { Surface } \\
\text { Material }\end{array}$ & $\begin{array}{c}\text { Current } \\
\text { Surface } \\
\text { Thickness }\end{array}$ & $\begin{array}{c}\text { Previous } \\
\text { Thickness }\end{array}$ & $\begin{array}{c}\text { Last } \\
\text { Construct- } \\
\text { ion year }\end{array}$ & $\begin{array}{c}\text { Last } \\
\text { rehabilitation }\end{array}$ & $\begin{array}{c}\text { Last } \\
\text { Surfacin } \\
\text { g }\end{array}$ & $\begin{array}{c}\text { Last } \\
\text { Inhibitive } \\
\text { Treatment }\end{array}$ \\
\hline RUP-01 & B.C & 75 & 50 & 2004 & 2009 & 2014 & 2015 \\
\hline RUP-02 & B.C & 75 & 50 & 2005 & 2010 & 2013 & 2014 \\
\hline RUP-03 & B.C & 75 & 50 & 2005 & 2011 & 2015 & 2015 \\
\hline
\end{tabular}

\subsection{Traffic Volume}

Traffic volume data is calculated after conducting counts for 72 hours by involving sufficient number of enumerator's for the corresponding road branches. In this scenario data is collected by Municipal Corporation Patiala (Department of town and country Planning Punjab) [2] mentioning the number of motorised and nonmotorised traffic in the Table 3 underneath. 
Table 3: Traffic Classification

\begin{tabular}{|c|c|c|c|c|}
\hline Section ID & Motorized AADT & $\begin{array}{c}\text { Non-Motorized } \\
\text { AADT }\end{array}$ & AADT Year & Traffic Volume \\
\hline RUP-01 & 15255 & 2219 & 2016 & High \\
\hline RUP-02 & 12856 & 2500 & 2016 & High \\
\hline RUP-03 & 9879 & 1500 & 2016 & Medium \\
\hline
\end{tabular}

\section{FUNCTIONAL AND STRUCTURAL EVALUATIONS}

One of the major functional evaluation parameter is roughness [4] which helps in predicting the surface condition of pavement. This disorder occurs due to distortion of road profile caused by the material and technique used during construction. These irregularities are measured with the help of roughometer or bump integrator such as AIM-9903. The operating speed of this machine is $32 \mathrm{~km} / \mathrm{hr}$ and is towed with the help of a motorised four wheeler transport vehicle which is usually a truck. The wheels of the roughometer runs on the pavement surface ,the vertical back and forth motion of the axle is converted into single directional motion .The accumulated value of the motion of the axle is recorded through a digital counter. Deflection is calculated by rebound mechanism using Benkleman Beam Deflection method (IRC 81:1997)[3] . Roughness was calculated using Odoki and Kerali Equation which converts Unevenness Index (UI) into International Roughness Index (IRI). [9]

$I R I=\left(U I \times \frac{1}{620}\right)^{1 / 1+12}(1)$

The adjusted SNP was calculated from deflection values taken from Benkleman beam Deflection (B.B.D)[3] method and using following equation by Odoki and Kerali :[9]

For granular base layers

$B B_{\text {def }}=6.5 \times(\mathrm{SNP})^{-1.6}(2)$

For bituminous layers

$B B_{\text {def }}=3.5 \times(\mathrm{SNP})^{-1.6}(3)$

Table 4 represents functional and structural evaluation data along with tweaked factors for HDM- 4 deterioration models [1].

Table 4: Structural and functional evaluation

\begin{tabular}{|c|c|c|c|c|}
\hline Section ID & Condition Year & IRI $(\mathbf{m} / \mathbf{k m})$ & B.B.D(mm) & SNP \\
\hline RUP -01 & 2016 & 2.16 & 0.49 & 5.0 \\
\hline RUP -02 & 2016 & 2.24 & 0.88 & 3.50 \\
\hline RUP -03 & 2016 & 3.87 & 2.14 & 2.0 \\
\hline
\end{tabular}

Table 5: Tweaked or Calibrated Factors

\begin{tabular}{|c|c|}
\hline Model Description & Average calibration factor \\
\hline Cracking Initiation Model & 0.43 \\
\hline Cracking Progression Model & 1.25 \\
\hline Ravelling Initiation Model & 0.37 \\
\hline Ravelling Progression Model & 0.52 \\
\hline Pothole Initiation Model & 0.45 \\
\hline Pothole Progression Model & 0.95 \\
\hline Roughness Progression Model & 0.85 \\
\hline Rutting Progression Model & 1.00 \\
\hline
\end{tabular}

\subsection{Proposed Maintenance and Rehabilitation Alternatives}

Five alternatives have been proposed for the given road section to meet the desired road user demand. The basic alternative (BS01) is the standard routine work which includes patching and cracking sealing occurring at an interval period of one year. Dual alternative (BS02) includes resealing through a $25 \mathrm{~mm}$ Double Bituminous Surface Dressing (DBSD) and a thin overlay of bituminous concrete being condition responsive provided 
between IRI ranges of 4 and 6.The primary alternative(BS03) provides a thick overlay of $40 \mathrm{~mm}$ scheduled after every 2 years. The secondary alternative is the used in the scenario when no other alternative is sufficient to cope up with the present pavement condition and the entire section of road is reconstructed providing a surface thickness of $130 \mathrm{~mm}$. Tertiary alternative (BS05) provides routine work, overlay and surface dressing with intervention criteria specified in Table 6[7]

Table 6: Maintenance alternatives for different working strategies

\begin{tabular}{|c|c|c|c|}
\hline Strategy & Work Standard & Description of work & Intervention Level \\
\hline \multirow{2}{*}{$\begin{array}{c}\text { Basic } \\
\text { Alternative(BS01) }\end{array}$} & \multirow[t]{2}{*}{ Routine } & Patching & Scheduled annually \\
\hline & & Crack Sealing & Scheduled annually \\
\hline \multirow{2}{*}{$\begin{array}{c}\text { Dual } \\
\text { Alternative(BS02) }\end{array}$} & Resealing & $25 \mathrm{~mm}$ DBSD & Damage area $>7.5 \%$ of total area \\
\hline & Thin Overlay & $25 \mathrm{~mm} \mathrm{BC}$ & $4<$ Roughness <6 IRI \\
\hline $\begin{array}{l}\text { Primary Alternative } \\
\text { (BS03) }\end{array}$ & Thick Overlay & $40 \mathrm{~mm} \mathrm{BC}$ & Scheduled to 2 years \\
\hline $\begin{array}{c}\text { Secondary } \\
\text { Alternative(BS04) }\end{array}$ & Reconstruction & $\begin{array}{c}\text { Surface Thickness } 130 \\
\text { mm }\end{array}$ & Roughness > 8 IRI \\
\hline $\begin{array}{l}\text { Tertiary Alternative } \\
\text { (BS05) }\end{array}$ & $\begin{array}{l}\text { Routine, Overlay, } \\
\text { Surface Dressing, }\end{array}$ & $\begin{array}{l}\text { Overlay } 50 \mathrm{~mm} \text {, Crack } \\
\text { Sealing, Surface } \\
\text { Dressing } 15 \%\end{array}$ & $\begin{array}{l}\text { Cracked area }>15 \% \text { of total area, } \\
\text { Roughness }>=6 \text { IRI, Skid Resistance } \\
<=0.4 \text { SFC, Severely Damaged }>= \\
5 \% .\end{array}$ \\
\hline
\end{tabular}

\subsection{Determination of Optimum M \& R strategy for all selected roads}

For road section RUP-01 reconstruction is triggered in the year 2023 which is under the secondary alternative BS04 at the end of year 2022, similarly the reconstruction is triggered in 2032 under the same intervention criteria. Primary alternative BS03 under which an overlay is provided has been scheduled after every two years is triggered in year 2034. The peak value of roughness for tertiary alternative BS05 is in terms of IRI which is the optimum alternative and is attained in year 2033 which comes out to be 6 as shown in Figure 1 below.

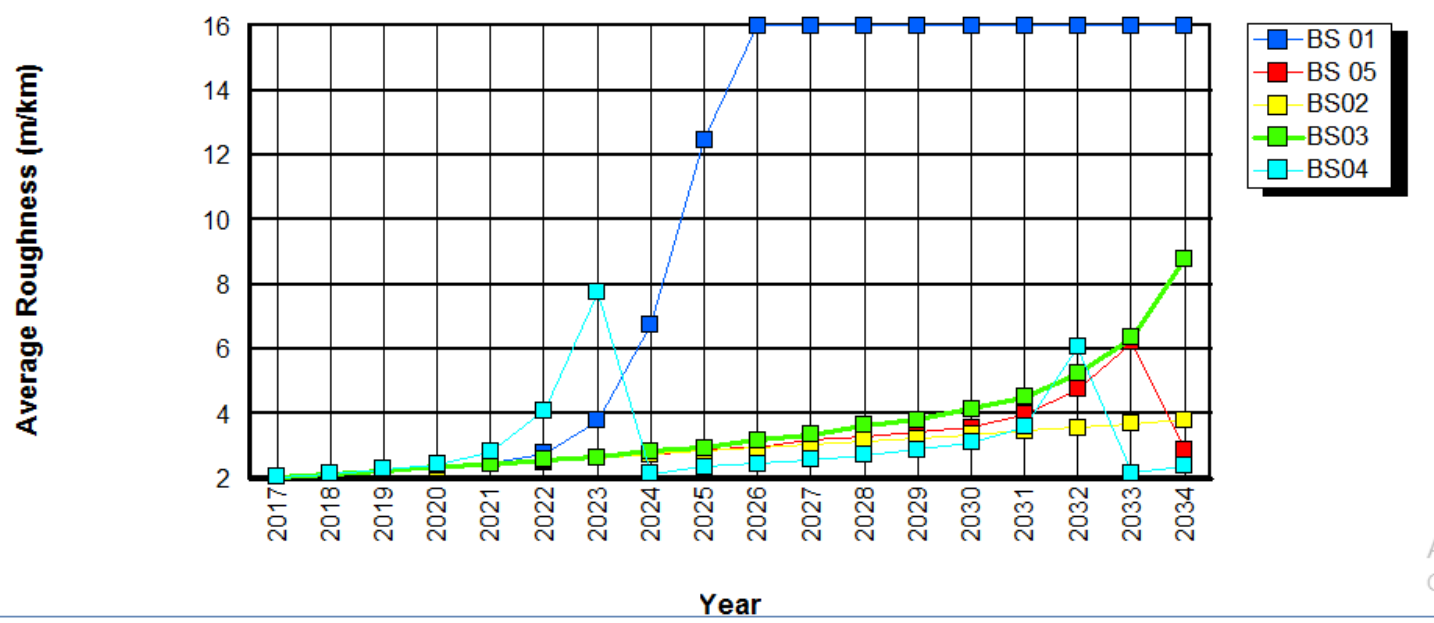

Figure 1 Roughness progression model under all alternatives for section RUP-01 
Due to secondary alternative(BS04) criteria reconstruction is triggered in 2023as shown in Figure 2 because in 2026 under tertiary alternative(BS05) routine work, overlay and surface dressing is done, which is a condition responsive alternative and is economical as compared to BS 04 .

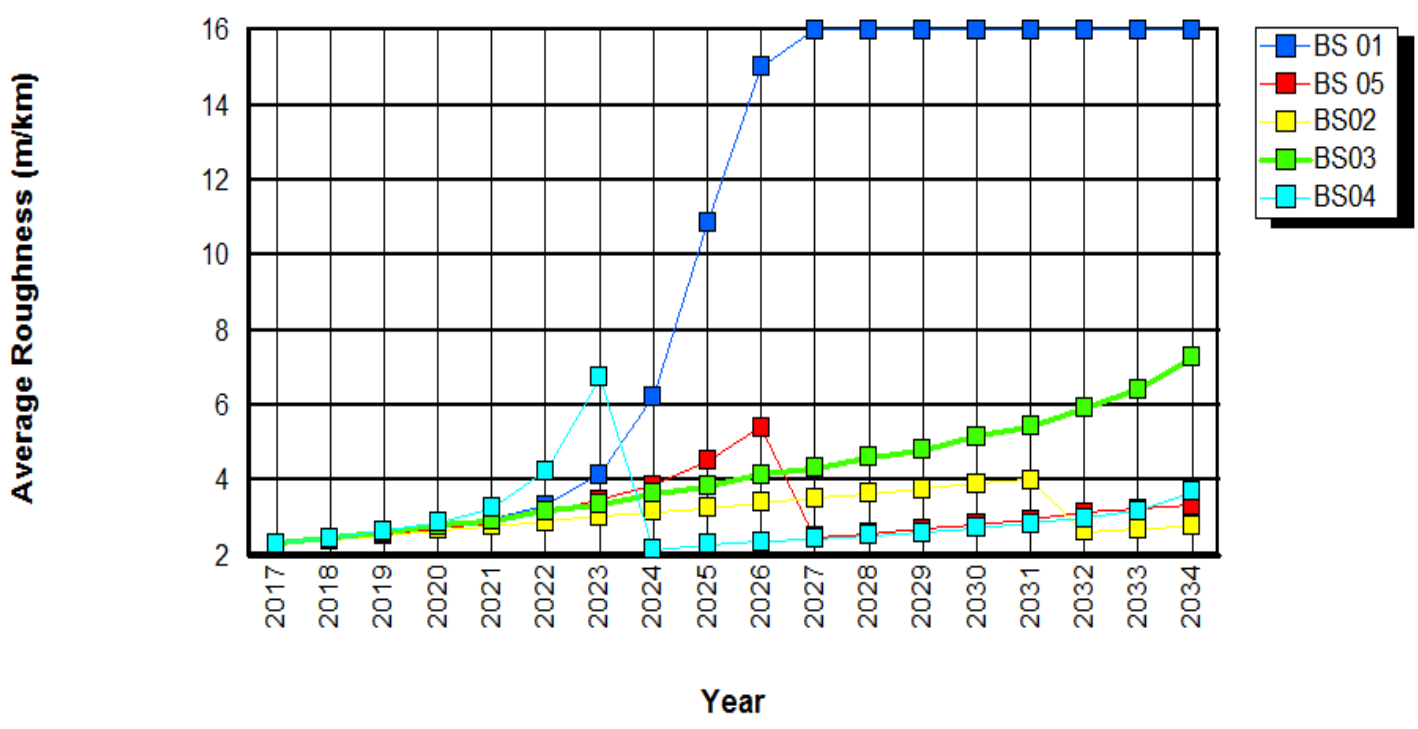

Figure 2 Roughness progression model under all alternatives for section RUP-02

When the roughness value reaches to 6 in terms of IRI in the year 2027 as shown in Figure 3, the tertiary alternative (BS05) comes into effect therefore delaying the construction period by 3 years i.e. BS04 alternative of reconstruction in year 2030 comes into effect, hence depicting the effectiveness of alternative BS05.

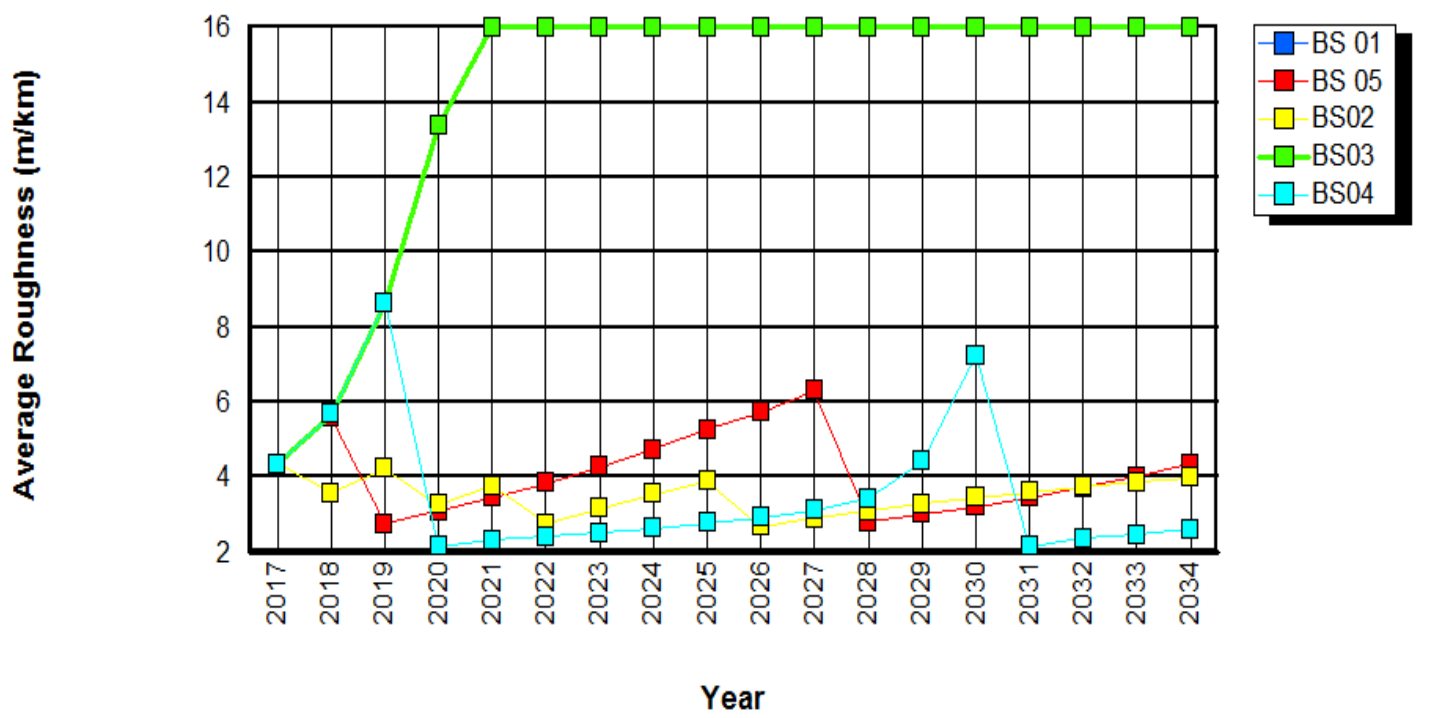

Figure 3 Roughness progression model under all alternatives for section RUP-03

\subsection{Vehicle Operating Cost}


Vehicle operating cost [8] is one of the vital components of road user cost which is to be calculated from the vehicle components:

$\begin{array}{ll}- & \text { Spare parts } \\ - & \text { Requirement of different lubricating oils } \\ - & \text { Crew wages of vehicle } \\ - & \text { Labour and maintenance costs } \\ - & \text { Vehicle devaluation and stake on capital }\end{array}$

Time Travel Costs

$\begin{array}{ll}- & \text { Distance travelled } \\ \text { - } & \text { Average vehicle speeds } \\ \text { - } & \text { Unit's cost per hour } \\ \text { - } & \text { Determining optimum budget }\end{array}$

These above two factors are playing important role in the road user costs for calculation of annual costs, periodic maintenance, improvements available within limited budget allocation. They may comprise of combination of one or more types of different road works.

Table 7: Vehicle operating cost input data for 1000 vehicles/km

\begin{tabular}{|c|c|c|c|c|c|}
\hline Parameters & $\begin{array}{c}\text { Animal } \\
\text { Driven } \\
\text { Cart }\end{array}$ & $\begin{array}{c}\text { Person (M } \\
\text { J) }\end{array}$ & Two Wheeler & $\begin{array}{c}\text { Light Goods } \\
\text { Freight }\end{array}$ & Heavy Truck \\
\hline Cost of Fuel(Rs/litre) & 0 & 1 & 620 & 500 & 800 \\
\hline Maintenance (Rs/hour) & 0 & 0 & 4 & 4 & 12 \\
\hline Crew Wage(Rs/hour) & 0.22 & 0 & 2 & 2 & 16 \\
\hline Overhead annual interest (\%) & 12 & 0 & 8 & 12 & 12 \\
\hline Cost of Lubricant(Rs/litre) & 0 & 0 & 0.25 & 8 & 12 \\
\hline
\end{tabular}

\subsection{Economic Analysis}

Cost analysis is a tool used for economic assessment for strengthening by the means of maintenance strategies with regard to selection of most effective maintenance strategy. This may be used to determine the optimum budget that will result in the highest rate of return on the behalf of investment laid as shown in Table 8 .

Table 8: Calculation of NPV/Cost Ratio and Internal Rate of Return

\begin{tabular}{|c|c|c|c|c|c|c|}
\hline Alternative & $\begin{array}{c}\text { Present Value } \\
\text { of Road } \\
\text { Agency } \\
\text { Cost(RAC) }\end{array}$ & $\begin{array}{c}\text { Increase } \\
\text { in } \\
\text { Agency } \\
\text { Cost }\end{array}$ & $\begin{array}{c}\text { Decrease } \\
\text { in Road } \\
\text { User } \\
\text { Cost }\end{array}$ & $\begin{array}{c}\text { Net Present } \\
\text { Value }\end{array}$ & $\begin{array}{c}\text { NPV/Cost } \\
\text { Ratio }\end{array}$ & $\begin{array}{c}\text { Internal } \\
\text { Rate of } \\
\text { Return } \\
\text { (IRR) }\end{array}$ \\
\hline BS01 & 0.201 & 0 & -828.22 & -827.21 & 0 & $* * *$ \\
\hline BS02 & 6.326 & 4.721 & 39.88 & 5.165 & 5.59 & 627 \\
\hline BS03 & 0 & -1.605 & -352.85 & -351.25 & 0 & $* * *$ \\
\hline BS04 & 1.605 & 0 & 0 & 0 & 0 & 0 \\
\hline BS05 & 0.261 & -1.344 & -0.747 & 0.598 & 2.973 & 11.7 \\
\hline
\end{tabular}

The above mentioned details are specific to Patiala city, Punjab, India at a discount rate of $12.0 \%$ [6]. The priority is given to the maintenance which possess maximum NPV value. Therefore maintenance with high Internal Rate of Return will qualify for prioritization. 
Table 9: Details of optimum Tertiary Alternative (BS05)

\begin{tabular}{|c|c|c|c|c|c|c|}
\hline Year & Section & Work Description & Code & $\begin{array}{l}\text { Economic } \\
\text { Cost }(\text { Rs. })\end{array}$ & $\begin{array}{l}\text { Financial } \\
\text { Cost(Rs.) }\end{array}$ & $\begin{array}{c}\text { Work } \\
\text { Quantity }\left(\mathbf{m}^{2}\right. \\
)\end{array}$ \\
\hline \multirow[t]{2}{*}{2017} & \multirow[t]{2}{*}{ TRIPURI ROAD } & Patching & PATCH & 1200.0 & 1440.0 & 100.00 \\
\hline & & Crack Sealing & CRKSL & 719.0 & 862.8 & 143.8 \\
\hline & Total Annual Cost & & & 1919.0 & 2302.8 & \\
\hline \multirow[t]{4}{*}{2018} & \multirow[t]{4}{*}{ SECTARIAN ROAD } & $\begin{array}{l}\text { Surface Dressing at } \\
15 \% \text { ADA }\end{array}$ & $\begin{array}{l}\text { S } \\
\text { DRESS }\end{array}$ & 3500.0 & 42000 & 7000.0 \\
\hline & & Prep Patching & & 3.9 & 4.6 & 0.32 \\
\hline & & Prep. Crack Sealing & & 1049 & 1258.2 & 209.79 \\
\hline & & Prep. Edge Repair & & 806.8 & 968.2 & 57.63 \\
\hline & \multirow[t]{3}{*}{ TRIPURI ROAD } & $\begin{array}{l}\text { Overlay } 50 \mathrm{~mm} \text { at } 6 \\
\text { IRI }\end{array}$ & OVL 50 & 90,000 & 108,000 & 6000 \\
\hline & & Prep Patching & & 1354.1 & 1624.9 & 112.84 \\
\hline & & Prep. Edge Repair & & 4562.6 & 5475.1 & 325.9 \\
\hline & Total Annual Cost & & & $132,776.3$ & $159,331.6$ & \\
\hline \multirow[t]{3}{*}{2019} & \multirow[t]{2}{*}{ RAJENDRA ROAD } & Patching & PATCH & 1200 & 1440 & 100 \\
\hline & & Crack Sealing & CRKSL & 6975.7 & 8370.9 & 1395.15 \\
\hline & Total Annual Cost & & & 8175.7 & 9810.9 & \\
\hline
\end{tabular}

Tertiary alternative (BS05) schedules routine surface dressing and overlay for the road network for analysis period of 18 years which comes out to be cost effective out of all maintenance strategies. BS05 is a conditioned responsive intervention criteria. The table 10above depicts the work description, economical and financial cost corresponding to each work item with the respective work quantity calculated annually.

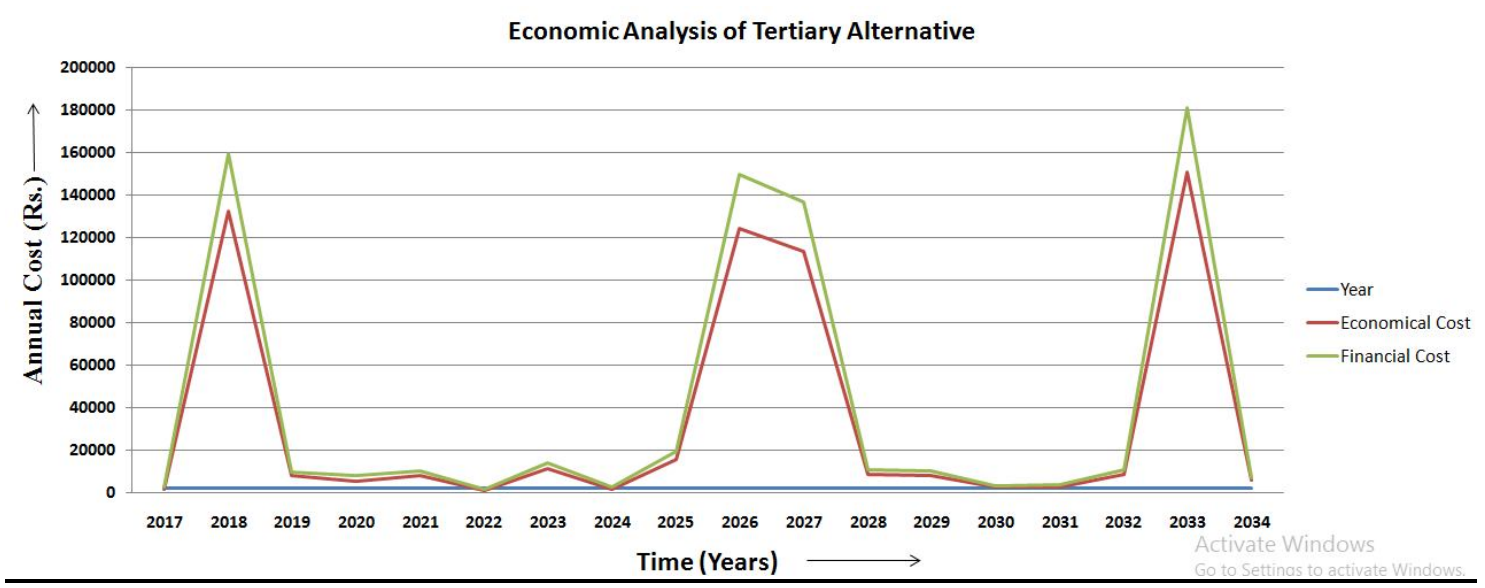

Fig 4 Annual Cost (Rs.) Vs Time (Years) 
It is clearly evident from the graph in Fig 4 that the economical cost is very less than the allotted financial cost from 2017-2034. As the financial cost increases with time, the economical cost also increases but in meagre amounts and is quite less as compared to financial cost. Therefore tertiary alternative is highly recommended alternative for pavement maintenance strategic point of view as it is efficient as well as low budget not only in consecutive years but also in long run.

\section{CONCLUSION}

- The Pavement Maintenance and Management System helps in identification of projects in need of maintenance by establishing priorities.

- The use of PMMS techniques can lead to coordinated response and strategy which is effective in minimizing the cost of pavements and fair distribution of funds.

- The alternative provided BS05 come out to be more effective out of all alternative as it consists of routine, overlay, surface dressing and therefore is considered to be optimum for all road sections. Thus, comes out to be cost effective for pavement.

- The HDM-4 is to be calibrated with respect to local conditions. It consists of calibration factors for cracking, roughness, potholing. It leads to prediction distress and maintenance strategies for road.

- The cost is compared with different alternatives for Rajendra road, Sectarian road, Tripuri road in which condition responsive strategy is chosen due to its economical range .

\section{REFERENCES}

[1]. C.Tanuj, P.Manoranjan, K.Naveen, M.Jyoti Development of Pavement Maintenance Management System of Urban Road Network Using HDM-4 Model. International Journal of Engineering and Applied Sciences Vol 9. Issue 1,2017 14-31.

[2]. Government of Punjab, Master Plan Patiala, Department of town and country Planning Punjab, 2011.

[3]. Indian Road Congress:81 1997 "Guidelines for Strengthening of Flexible Road Pavements Using Benkelman Beam Deflection Technique".

[4]. Indian Road Congress: SP: 16-2004Guidelines For The Surface Evenness Of Highway Pavements (First Edition).

[5]. IRC-37:2015 - Guidelines for the Design of Flexible Pavements (Third Revision).

[6]. IRC SP:30, Manual on economic evaluation of highway projects in India. Journal of India Roads Congress, New Delhi, 2009.

[7]. MORT\&H, Specifications for maintenance works. Ministry of Road Transport \& Highways, Government of India, New Delhi, 2013.

[8]. MORT\&H, Guidelines for maintenance management of primary, secondary and urban roads. Ministry of Road Transport \& Highways, Government of India, New Delhi, 2004.

[9]. Odoki, J.B. and Kerali, H.R., Analytical framework and model descriptions. The World Road Association (PIARC) on behalf of the ISOHDM sponsors, 2013. 